UDC 94(470.4)“1953/1985”:373.24

Submitted: 06.05.2019

LBC 63.3(235.4)63-206

Accepted: 26.11.2019

\title{
REFORM OF THE NETWORK OF PRESCHOOL INSTITUTIONS IN THE SOVIET UNION IN THE SECOND HALF OF THE 1950s TO THE MID-1980s (ON THE MATERIALS OF THE LOWER VOLGA REGION)
}

\author{
Alexey A. Gumenyuk \\ Saratov State University named after N.G. Chernyshevskiy, Saratov, Russian Federation
}

\begin{abstract}
Introduction. The paper is devoted to analyzing the main lines of modernization of kindergartens and nurseries in the Lower Volga region in the second half of the 1950s to the mid-1980s. Materials. The article is based on the factual material extracted from the funds of the central and local archives, reporting and paperwork, legislative documents, and statistical collections. Methods. The study is based on a set of methodological techniques, including special methods of historical studies such as the historical-comparative, statistical and quantitative methods. Analysis. Analyzing a wide array of statistical data allows to make a number of important observations and to conclude that by the mid-1980s the above-mentioned institutions in the region under study had higher quantitative development indicators in comparison with the neighboring oblasts and republics in the Volga economic district, as well as in comparison with the all-Russian and even all-Union levels. Results. In conclusion, the author infers that by spring 1985, services of nurseries and kindergartens really became more accessible to the residents of the region under study. However, based on the qualitative criteria, we see that the level of their services reached by 1985 could not yet meet the growing needs of the population, especially in the countryside.

Key words: children, kindergarten, natural increase, complaint, request, family, institutions of motherhood and childhood.

Citation. Gumenyuk A.A. Reform of the Network of Preschool Institutions in the Soviet Union in the Second Half of the 1950s to the Mid-1980s (On the Materials of the Lower Volga Region). Vestnik Volgogradskogo gosudarstvennogo universiteta. Seriya 4. Istoriya. Regionovedenie. Mezhdunarodnye otnosheniya [Science Journal of Volgograd State University. History. Area Studies. International Relations], 2020, vol. 25, no. 3, pp. 56-65. (in Russian). DOI: https://doi.org/10.15688/jvolsu4.2020.3.5
\end{abstract}

\section{РЕФОРМИРОВАНИЕ СЕТИ ДЕТСКИХ ДОШКОЛЬНЫХ УЧРЕЖДЕНИЙ В СССР ВО ВТОРОЙ ПОЛОВИНЕ 1950-х - СЕРЕДИНЕ 1980-Х ГГ. (ПО МАТЕРИАЛАМ НИЖНЕГО ПОВОЛЖЬЯ)}

\author{
Алексей Анатольевич Гуменюк \\ Саратовский государственный университет им. Н.Г. Чернышевского, г. Саратов, Российская Федерация
}

\footnotetext{
Аннотация. Введение. В работе анализируются основные направления модернизации детских садов и яслей в регионе Нижней Волги во второй половине 1950-х - середине 1980-х годов. Методы. Исследование базируется на использовании комплекса методологических приемов, включающих такие специальные методы исторической науки, как историко-сравнительный, статистический и количественный. Maтериальl. Статья основана на фактическом материале, извлеченном из фондов центральных и местных архивов, отчетной и делопроизводственной документаций, директивно-законодательных документов, статистических сборников. Анализ. Привлечение широкого массива статистических данных дало возможность осуществить ряд наблюдений и определить, что изучаемый регион к середине 1980-х гг. имел более высокие количественные показатели развития указанных учреждений как по сравнению с соседними областями и республиками () Поволжского экономического района, так и республиканским и даже общесоюзным уровнями. Результа-
} 
mbl. Делается вывод о том, что к весне 1985 г. услуги детских яслей и садов действительно стали более доступными жителям изучаемого региона. Если исходить из качественного критерия, то достигнутый к 1985 г. уровень обслуживания ими населения, даже несмотря на все имевшиеся в этом отношении достижения и успехи, не мог удовлетворить растущие потребности населения, особенно в сельской местности.

Ключевые слова: дети, детский сад, естественный прирост, жалоба, наказ, семья, учреждения материнства и детства.

Цитирование. Гуменюк А. А. Реформирование сети детских дошкольных учреждений в СССР во второй половине 1950-х - середине 1980-х гг. (по материалам Нижнего Поволжья) // Вестник Волгоградского государственного университета. Серия 4, История. Регионоведение. Международные отношения. - 2020. T. 25, № 3. - C. 56-65. - DOI: https://doi.org/10.15688/jvolsu4.2020.3.5

Введение. В 2017 г. уровень рождаемости в Российской Федерации превысил показатели 1997 г. более чем в 1,3 раза [36]. Указанная позитивная тенденция выступает важнейшим показателем эффективности реализации федеральной программы по решению демографической проблемы и служит важным стимулом для расширения сети детских дошкольных учреждений. Если в 1998 г. в РФ детские сады посещало лишь 53,9 \% детей, то в 2017 г. этот показатель составил 64,6 \%. В то же время этот процесс еще не до конца удовлетворяет потребности населения в этих учреждениях. Вне детских садов в 2017 г. находилось на 1,8 \% больше детей, чем в 1990 году. Исследование, проведенное в 2017 г. учеными Института социального анализа и прогнозирования Российской академии народного хозяйства и государственной службы при Президенте РФ (РАНХиГС), показало, что нынешнее положение с обеспечением населения сетью дошкольных учреждений напоминает ситуацию 1990 г.: при сравнительно высоком охвате детей дошкольным образованием группы переполнены [6].

Вывод, сделанный исследователями РАНХиГС, выступает ярким свидетельством негативного влияния на российское общество утвердившейся с начала постсоветского этапа отечественной истории неолиберальной модели развития, пропагандирующей монетаристскую философию. Технология ее претворения в жизнь базируется прежде всего на минимизации роли государства в обществе, отказе от своих социальных функций. Таким образом, на наш взгляд, в РФ наблюдается отказ государства от выполнения своих социальных функций, хотя по Конституции Россия является именно социальным государством (ст. 7).
Особенно остро последствия функциональной трансформации государства россияне стали ощущать с началом в 2008 г. масштабного экономического кризиса, усугубленного санкционной политикой Запада в 2014 году. Эти два события окончательно разрушили иллюзии социальной защищенности населения и довольно высокого уровня жизни, поддерживаемые ранее высокими ценами на нефть даже после уничтожения производящих отраслей промышленности. Эти обстоятельства делают исключительно значимым и актуальным изучение проблем реформирования сети детских дошкольных учреждений во второй половине 1950-х - середине 1980-х гг. как важного направления советской социальной политики в условиях «полной автономности» советской экономики. К тому же именно это тридцатилетие было относительно спокойным, лишенным каких-либо социальных потрясений, периодом отечественной истории, когда была предпринята попытка тотального пересмотра взглядов на социализм как общественно-экономическую модель, направленную на удовлетворение социальных нужд трудящихся. Однако в современной исторической науке рассматриваемая в статье проблема так и не стала объектом самостоятельного исследования, выступая составной частью обобщающих работ по истории Отечества, отдельных регионов РФ и истории здравоохранения второй половины ХХ века.

После завершения Второй мировой войны в Европе стала ощущаться потребность в новой социальной политике, что выразилось в разработке и реализации ряда социальных программ помощи ее населению. Как первое в мире социалистическое государство, Советский Союз должен был бы стать лидером в этом процессе, однако тогдашнее советское 


\section{СССР: ПРОБЛЕМЫ СОВЕТСКОЙ МОДЕРНИЗАЦИИ}

руководство рассматривало социальную политику как второстепенное направление внутренней политики страны. Исходя из сталинской формулы, ассоциирующей наступление социализма с достижением определенного уровня в развитии тяжелой промышленности, рассматриваемая сфера социального развития финансировалась, как и до войны, по остаточному принципу. Поэтому существовавшие на Нижней Волге детские дошкольные учреждения размещались в неприспособленных тесных помещениях, ощущался дефицит мебели, белья, посуды, игрушек. Имели место хищения продуктов. От родителей поступали жалобы на то, что их дети питались черствым хлебом, пили несладкий чай, не получали овощей и фруктов, мало потребляли молока и мяса. Из-за привлечения работников детских садов на полевые работы, хотя это законодательно было запрещено, многие сельские и районные детсады испытывали дефицит квалифицированных воспитателей и медработников [32, л. 17]. Санитарно-гигиенические нормы размещения детей в детских садах нарушались. Так, в Кировском районе г. Саратова в 1953 г. вместо положенных по нормам 468 детей в детсадах размещалось 530. В одном из сельских районов Саратовской области на одного ребенка в детском саду приходилось лишь 0,9 кв. м, что на 1,6 кв. м было ниже существовавших норм [3, л. 6,81$]$. Нарушение утвержденных санитарной инспекцией нормативов вело к росту заболеваемости детей различными инфекционными заболеваниями, уровень которой нередко превышал средние по РСФСР показатели.

Методы и материалы. Исследование реформирования сети детских дошкольных учреждений базируется на использовании таких специальных методов исторической науки, как историко-сравнительный, статистический и количественный. С помощью историко-сравнительного метода удалось сопоставить ситуацию в рассматриваемом сегменте социального развития Астраханской, Волгоградской, Саратовской областей и Калмыцкой ACCP, в регионе Нижнего Поволжья и Российской Федерации в целом. Обращение к статистическому методу анализа источников позволило создать необходимый информативный фон исследования, а количественный анализ высказываний и жалоб, обнаруженных при обработке наказов избирателей, а также стенограмм партийных, профсоюзных конференций и сессий Советов различного уровня позволил составить пространственно-временную характеристику полученных данных. Выявленные характеристики дали возможность проиллюстрировать существовавшие различия в уровне обеспеченности услугами детских дошкольных учреждений населения отдельных административно-территориальных образований региона. Статья основана на фактическом материале, извлеченном из фондов центральных и местных архивов, отчетной документации, статистических сборников.

Анализ. Реформы системы учреждений материнства и детства в постсталинский период базировались на основных принципах социальной стратегии Советского государства, а именно стремлении обеспечить равные возможности всем категориям населения СССР в доступе к высококвалифицированным услугам указанных учреждений. Выработка необходимой для этого директивно-законодательной базы началась 12 августа 1953 г., когда Президиум ЦК КПСС в развитие предложенных Г.М. Маленковым на Пятой сессии Верхового Совета СССР мер принял решение о подготовке соответствующего постановления [2, л. 137]. Н.С. Хрущев как новый партийный лидер также в сентябре 1953 г. на Пленуме ЦК КПСС охарактеризовал те возможности, которые позволят колхозам в условиях начавшегося реформирования сельского хозяйства больше уделять внимания расширению сети детских дошкольных учреждений $[8$, с. 341,344$]$. Эти учреждения предписывалось строить строго по типовым проектам, в том числе и в сельской местности. Малообеспеченные и многодетные семьи этими учреждениями должны были обслуживаться бесплатно. Это положение было внесено не только в соответствующий раздел принятой 31 октября 1961 г. на XXII съезде КПСС очередной программы партии [28, c. 96-97], но и в проект новой конституции, принятие которой планировалось осуществить в 1964 г. [31, с. 414].

Своим пристальным вниманием к проблемам модернизации детских дошкольных учреждений коллективное советское руковод- 
ство демонстрировало приверженность общеевропейской политике по материальной поддержке молодых, многодетных и малообеспеченных семей. Необходимость существенного реформирования сети указанных учреждений была обусловлена и постепенным ростом рождаемости. С 1950 по 1960 г. естественный пророст населения Нижней Волги в среднем возрос в 1,2 раза, что было характерно и для других экономических районов РСФСР, например для Южного Урала (опережение этого региона Нижним Поволжьем в 1960 г. составляло всего 0,1 раза) [9, с. 63]. Наибольшее увеличение коэффициента естественного прироста населения наблюдалось в Калмыцкой АССР - в 1,6 раза. По этому показателю в середине 1960-х гг. республика занимала третье место в РСФСР [5, с. 49].

Опираясь на принятые в 1953-1964 гг. постановления партии и правительства, власти Нижнего Поволжья осуществили широкий комплекс мероприятий по улучшению функционирования указанных заведений (табл. 1).

Анализ данных этой таблицы показывает, что наиболее эффективно эта проблема решалась в Сталинградской (Волгоградской) области. Прирост сети детских дошкольных учреждений в этом субъекте РСФСР с 1950 по 1964 г. составил 2,5 раза, а число детей, обслуженных ими, возросло в 6,4 раза. На остальной территории региона первый показатель колебался от 1,4 раза (Астраханская область) до 1,9-2 раз (Саратовская область и Калмыцкая АССР). Показатели прироста ох- вата детей детскими садами и яслями-садами разнились от 3,4 раза (Астраханская область) до 3,6-3,8 раза (Саратовская область и Калмыцкая АССР).

Несмотря на значительную разницу характеристик развития сети дошкольных учреждений население региона выражало свое удовлетворение их деятельностью. Например, от жителей Саратовской области в 1961 г. в облсовет поступило всего 5,5 \% различных жалоб по данной проблеме [13], в Верховный Совет Калмыцкой АССР в 1963 г. - только $6 \%$ [11]. В областной совет депутатов трудящихся Волгоградской области за 19621965 гг. поступление таких наказов снизилось на $8,1 \%$, составив в 1965 г. всего 5,7 \% [15; 16]. Как видно из данных таблицы 1 , охват детей детскими учреждениями региона был выше аналогичного показателя в целом по Поволжскому экономическому району (в 1,7 раза) и республиканского уровня (более чем в 2 раза). При этом государство стремилось как можно в большем объеме взять на себя затраты на содержание детей в дошкольных детских учреждениях. Например, семьи саратовских рабочих за пользование услугами детских садов и яслей в третьем квартале 1955 г. заплатили в 1,2 раза меньше денежных средств, чем за аналогичный период 1954 г. [34, л. 285-286].

Однако в условиях сохранения приоритетного финансирования тяжелой и оборонной промышленности, роста расходов на оборону, средства, выделяемые государством

\section{Таблица 1. Детские сады и ясли Нижнего Поволжья в 1950-1964 гг.}

\section{Table 1. Kindergartens and nurseries of the Lower Volga region in 1950-1964}

\begin{tabular}{|c|c|c|c|c|}
\hline \multirow[b]{2}{*}{ Регион } & \multicolumn{2}{|c|}{1950 г. } & \multicolumn{2}{|c|}{1964 г. } \\
\hline & $\begin{array}{c}\text { Кол-во } \\
\text { дошкольных } \\
\text { учреждений }\end{array}$ & $\begin{array}{c}\text { Численность } \\
\text { детей в детских } \\
\text { садах и яслях }\end{array}$ & $\begin{array}{c}\text { Кол-во } \\
\text { дошкольных } \\
\text { учреждений }\end{array}$ & $\begin{array}{c}\text { Численность } \\
\text { детей в детских } \\
\text { садах и яслях }\end{array}$ \\
\hline Астраханская область & 144 & 5322 & 208 & 17900 \\
\hline $\begin{array}{l}\text { Сталинградская (Вол- } \\
\text { гоградская) область }\end{array}$ & 211 & 8421 & 538 & 54000 \\
\hline Саратовская область & 365 & 16373 & 683 & 58900 \\
\hline \multirow[t]{2}{*}{ Калмыцкая АССР } & \multicolumn{2}{|c|}{1957 г. } & \multirow[t]{2}{*}{47} & \multirow[t]{2}{*}{2900} \\
\hline & 23 & 769 & & \\
\hline $\begin{array}{l}\text { Поволжский эконо- } \\
\text { мический район }\end{array}$ & 2140 & 133700 & 4183 & 344700 \\
\hline \multirow[t]{2}{*}{ РСФСР } & \multicolumn{2}{|c|}{1958 г. } & \multirow[t]{2}{*}{40462} & \multirow[t]{2}{*}{3522000} \\
\hline & 25472 & 1653800 & & \\
\hline
\end{tabular}

Примечание. Составлено по данным: [17, с. $60 ; 18$, с. $126 ; 20$, с. 498; 21, с. 494; 23, с. 423; 24, с. 256]. 


\section{СССР: ПРОБЛЕМЫ СОВЕТСКОЙ МОДЕРНИЗАЦИИ}

на развитие сети детских дошкольных учреждений, не позволяли довести уровень развития их материально-технической базы до рубежей, обозначенных в постановлениях, принятых партией и правительством. Так, жители Сталинградской (Волгоградской) области только за 1961 г. «недополучили детских яслей и садов на 1750 мест» [26, л. 59]. Число мест в таких учреждениях Калмыцкой АССР отставало от потребности населения в них в начале 1960-х гг. в 5 раз [35, л. 55]. Анализ количественных показателей в собранном нами материале по Саратовской области показывает, что если в 19531958 гг. делегатами партийных конференций и депутатами сессий советов различного уровня было высказано 77 жалоб по поводу дефицита сети детских садов, яслей и неудовлетворительного состояния функционировавших, то за 1959-1964 гг. - уже 145 таких высказываний.

Состоявшийся в марте 1965 г. Пленум ЦК КПСС дал старт новой программе реформ в стране, в ходе которых различные направления социальной сферы получили новые финансовые вливания, что позволило усилить прежде всего количественные показатели их развития. Этот процесс не обошел стороной и детские дошкольные учреждения. Например, в Астраханской области обеспеченность детей местами в дошкольных учреждениях только за 1970-1975 гг. возросла в 1,5 раза [25, c. 169]. В Саратовской области в 1965-1984 гг. этот показатель увеличился в 2,7 раза [1, c. $102 ; 4$, л. 26]. Позитивные изменения в функционировании сети указанных учреждений региона являлись отражением стабилизации (начиная с 1970 г.) естественного прироста населения в регионе. По этому показателю особо выделялась Калмыцкая АССР, где в 1971-1973 гг. естественный прирост был выше среднего по СССР [7, с. 114]. Население региона весьма позитивно отзывалось о функционировании детских дошкольных учреждений. Так, в Астраханской области количество наказов, поданных жителями этого субъекта РСФСР с 1971 по 1973 г. снизилось на 1,7\% $[12 ; 30]$.

Постепенное угасание импульса, который получила советская экономика в ходе реализации экономической реформы 1965 г., и обо- стрение отношений между СССР и США в конце 1970-х гг. существенно ограничили финансовые возможности государства по выполнению взятых на себя социальных обязательств. Поэтому население Нижнего Поволжья ощущало нехватку детских садов и яслей, особенно в сельской местности. В функционировавших яслях и садах не хватало педагогов, медицинских работников, они плохо снабжались продуктами (имели место даже хищения), были упущения в организации питания воспитанников этих учреждений (трехразовое, а не четырехразовое питание, плохое качество продуктов, скудное меню, в основном состоящее из макаронных и мучных продуктов). Имеющаяся сеть детских дошкольных учреждений была переуплотнена. Например, в конце 1970-х гг. в Саратовской области в ясельных группах площадь на одного ребенка составляла всего 1,7-1,9 кв. м при норме 2,5 кв. м; в садиковых группах - 1,3 кв. м при норме 2-2,5 кв. м [29, л. 43]. Переуплотнение в детских комбинатах Михайловского, Палласовского, Суровикинского районов Волгоградской области в это время колебалось от 26 до $44 \%$ [33, л. 139].

Таким образом, обострившиеся во второй половине 1970-х - середине 1980-х гг. проблемы, связанные с функционированием сети рассматриваемых учреждений, доказывают обоснованность жалоб женской части населения региона, адресованных в органы власти. Например, поступление таких жалоб в Саратовский областной совет депутатов трудящихся в период с 1976 по 1982 г. возросло в 1,5 раза $[14 ; 27]$. В то же время в указанный период по сравнению с первым постхрущевским десятилетием количество жалоб населения этой области на дефицит, низкие темпы строительства и необустроенность детских дошкольных учреждений сократилось в 2 раза. В конце 1970-х - начале 1980-х гг. руководство данного субъекта РСФСР в своих выступлениях отмечало факт практически полной обеспеченности трудящихся области (в том числе и в сельской местности) услугами детских дошкольных учреждений. К началу 1985 г. этот показатель составлял 74 \% [10, л. 54]. Данные архивных документов подтверждаются и статистическими сведениями (см. табл. 2). 
Таблица 2. Численность детей в детских учреждениях Нижней Волги в 1955-1985 гг. Table 2. The number of children in children's institutions of the Lower Volga in 1955-1985

\begin{tabular}{|l|c|c|}
\hline \multirow{2}{*}{\multicolumn{1}{|c|}{ Регион }} & \multicolumn{2}{|c|}{ Численность детей } \\
\cline { 2 - 3 } & 1955 г. & 1985 г. \\
\hline Астраханская область & 6800 & 60000 \\
\hline Сталинградская (Волгоградская) область & 13900 & 108000 \\
\hline Саратовская область & 18400 & 161000 \\
\hline Калмыцкая АССР & $800(1957$ г.) & 20000 \\
\hline Поволжский экономический район & 98500 & 1190000 \\
\hline РСФСР & 1226700 & 8967000 \\
\hline
\end{tabular}

Примечание. Составлено по данным: [19, с. 355-356; 20, с. 498; 22, с. 267-269].

Анализ данных, представленных в таблице 2, позволяет сделать вывод о том, что в среднем по региону темпы прироста охвата детей данными учреждениями с середины 1950-х гг. до конца рассматриваемого периода возросли в 12,5 раз, что превышало аналогичный показатель по Поволжскому экономическому району (в 12 раз). Наилучшим образом проблема обеспечения детского населения постоянными дошкольными учреждениями была решена в Калмыцкой АССР, где прирост их сети возрос в 25 раз, что было следствием повышенного внимания руководства РСФСР к этой республике в период ее воссоздания (1956-1959 гг.). На остальной территории региона указанный показатель колебался от 8 до 9 раз, что было выше аналогичного показателя в среднем по РСФСР (в 7 раз).

Результаты. Таким образом, во второй половине 1950-х - середине 1980-х гг. на территории Нижнего Поволжья проводились мероприятия по обеспечению доступности всем категориям населения услуг детских дошкольных учреждений, а малообеспеченным и многодетным семьям - на бесплатной основе. Оценить результативность предпринятых в предперестроечное тридцатилетие усилий по модернизации указанных учреждений можно по двум критериям - количественному и качественному. Первый показатель доказывает, что к 1985 г. по сравнению с серединой 1950-х гг. услуги детских яслей и садов стали доступны населению Нижнего Поволжья, проживавшему не только в городской, но и в сельской местности. Функционирование этих учреждений стало неотъемлемой частью повседневной жизни волжан. К тому же по ко- личественным показателям развития сети детских дошкольных учреждений изучаемый регион к середине 1980 -х гг. на 0,5 раза опережал соседние области и республики Поволжского экономического района. Анализ развития сети указанных учреждений на примере Нижнего Поволжья с позиций второго критерия показывает, что количественные характеристики их развития не приводили к повышению качества жизни волжан, особенно в конце 1950 -х - начале 1960 -х гг. и во второй половине 1970-х - начале 1980-х годов. Данный тезис подтверждает приведенная выше динамика увеличения жалоб населения региона по поводу функционирования детских садов и яслей на протяжении указанных периодов. Таким образом, приведенный в статье анализ развития сети детских дошкольных учреждений убедительно доказывает, что к 1985 г. нижневолжский социум так и не достиг провозглашаемой руководством страны стадии «развитого социализма» и находился, скорее всего, лишь на ранней стадии становления «социалистической модели». Добиться более высоких показателей качества жизни советских людей не позволял дефицит экономических возможностей, порожденный противоречием между прогрессивно-перспективной моделью социальной политики и сохранявшимся на протяжении всего постсталинского периода приоритетным финансированием ВПК и отраслей, производящих станки и оборудование.

\section{СПИСОК СОКРАЩЕНИЙ}

ГААО - Государственный архив Астраханской области. 
ГАВО - Государственный архив Волгоградской области.

ГАНИСО - Государственный архив новейшей истории Саратовской области.

ГАРФ - Государственный архив Российской Федерации. области.

ГАСО - Государственный архив Саратовской мыкия.

НАРК - Национальный архив республики Кал-

РГАНИ - Российский государственный архив новейшей истории.

ЦДНИВО - Центр документации новейшей истории Волгоградской области.

\section{СПИСОК ЛИТЕРАТУРЫ}

1. Васильева, Л. Ф. Роль женщины в социально-экономической и политической сферах советского общества в 1945-1965 гг. (на материалах Саратовской области) : дис. ... канд. ист. наук / Васильева Лариса Ефимовна. - Саратов, 2004. - 247 с.

2. Выписка из протокола № 25 заседания Президиума ЦК КПСС (от 12 августа 1953 г.) // РГАНИ. Ф. 3. - Оп. 31. - Д. 17. - 170 л.

3. Доклад о состоянии развития сети детских дошкольных учреждений Саратовской области в 1953 г. // ГАНИСО. -Ф. 594. - Оп. 2. - Д. 2713. - 318 л.

4. Доклад о состоянии развития сети детских дошкольных учреждений Саратовской области в 1984 г. // ГАНИСО. - Ф. 6164. - Оп. 8-пр. - Д. 1385. - 52 л.

5. Заседания Верховного Совета Калмыцкой АССР третьего созыва, шестая сессия (27 июля 1966 г.) : стеногр. отчет. - Элиста : Калмиздат, 1966. -66 с.

6. Исследование: детские сады в РФ недоступны для $35 \%$ детей // TASS.RU. - 2017. - 21 марта. - Электpoн. текстовые дан. - Режим доступа: https://tass.ru/ obschestvo/4114004 (дата обращения: 10.04.2019). - Загл. с экрана.

7. Касимовский, Е. В. Роль производительности труда в повышении благосостояния народа на современном этапе / Е. В. Касимовский // Социалистический образ жизни и народное благосостояние. - Саратов : Изд-во Сарат. ун-та, 1975. C. $110-120$.

8. КПСС в резолюциях и решениях съездов, конференций и пленумов ЦК (1898-1988). В 16 т. Т. 8. 1946-1955. - 9-е изд., доп. и испр. - М. : Политиздат, 1985. - $542 \mathrm{c.}$

9. Леонтьева, Е. А. Социальная политика на Южном Урале в период правления Н.С. Хрущева : дис. ... канд. ист. наук / Леонтьева Евгения Анатольевна. - Оренбург, 2013. - 237 с.

10. Материалы к отчетному докладу на XVI Саратовской областной межсоюзной конферен- ции профсоюзов (от 26 января 1985 г.) // ГАНИСО. Ф. 6164. - Оп. 8. - Д. 1416. - 342 л.

11. Материалы по наказам избирателей депутатам Верховного Совета Калмыцкой АССР (от 20 апреля 1962 г.) //НАРК. -Ф. Р-1. -Оп. 4. - Д. 175. - 157 л.

12. Наказы избирателей кандидатам в депутаты областного Совета // ГААО. - Ф. Р-2233. Оп. 15. - Д. 339. - 423 л.

13. Наказы избирателей депутатам областного Совета VIII созыва и материалы по их выполнению // ГАСО. - Ф. Р-1738. - Оп. 1. - Д. 1068. - 169 л.

14. Наказы избирателей депутатам областного Совета и материалы по их выполнению // ГАСО. Ф. Р-1738. - Оп. 8. - Д. 1254. - 184 л.

15. Наказы и предложения избирателей, высказанные при встречах депутатов Верховного Совета СССР и областного Совета // ГАВО. Ф. Р-2115. - Оп. 6. - Д. 1877. - 131 л.

16. Наказы и предложения избирателей, данные депутатам Облсовета в 1965 г. // ГАВО. Ф. Р-2115. - Оп. 6. - Д. 2026. - 163 л.

17. Народное хозяйство Астраханской области : стат. сб. -Саратов : Госстатиздат, 1958. - 160 с.

18. Народное хозяйство Калмыцкой АССР : стат. сб. - Элиста : Калмиздат, 1960. - 137 с.

19. Народное хозяйство РСФСР : стат. сб. - М. : Госстатиздат, 1957. - $372 \mathrm{c.}$

20. Народное хозяйство РСФСР в 1958 году : стат. ежегодник. - М. : Госстатиздат, 1959. - 508 с.

21. Народное хозяйство РСФСР в 1964 году : стат. ежегодник. - М. : Статистика, 1965. - 576 с.

22. Народное хозяйство РСФСР в 1985 году : стат. ежегодник.-М. : Финансы и статистика, 1986. -397 с.

23. Народное хозяйство Саратовской области за 50 лет Советской власти : стат. сб. - Саратов : Статистика, 1967. - 454 с.

24. Народное хозяйство Сталинградской области : стат. сб. - Саратов : Госстатиздат, 1957. - 319 с.

25. Основные направления развития производительных сил Астраханской области на период до 1990 года : науч. докл. - М. : Центр. науч.-исслед. эксперимент, Ин-т Госплана СССР, 1978. - 243 с.

26. Отчетный доклад Волгоградского областного совета профессиональных союзов за 19601961 гг. на VII Волгоградской областной межсоюзной конференции профсоюзов (2-3 марта 1962 г.) // ГАВО. - Ф. Р-523. - Оп. 1. - Д. 858. - 220 л.

27. Перечень наказов избирателей депутатам областного Совета депугатов // ГАСО. -Ф. Р-1738. Оп. 8. - Д. 2014-а. - 190 л.

28. Программа Коммунистической партии Советского Союза : Принята ХХІІ съездом КПСС. М. : Политиздат, 1976. - 144 с.

29. Протокол V сессии Саратовского областного Совета (от 23 марта 1978 г.) // ГАСО. - Ф. Р-1738. Оп. 8. - Д. 1429-а. - 70 л. 
30. Протоколы предвыборных собраний избирателей, посвященных встрече с кандидатами в депутаты областного совета депутатов трудящихся // ГААО. Ф. Р-2233. - Оп. 15. - Д. 514. - 478 л.

31. Пыжиков, А. В. Хрущевская «оттепель» / А. В. Пыжиков. - М. : ОЛМА-ПРЕСС, 2002.-511 с.

32. Работа организационно-методических кабинетов областных и республиканских больниц по лечебно-профилактической помощи детям. Роль и организационные формы работы детского отделения больницы : докл. на Всерос. совещ. гл. врачей респ., краев., обл. больниц по обмену опытом работы 25-29 окт. 1955 г. // ГАРФ. - Ф. А-482. - Оп. 50. Д. 213. - 202 л.

33. Справка о состоянии воспитания и обслуживания детей в дошкольных учреждениях области в свете требований XXV съезда КПСС (от 27 июля 1976 г.) // ЦДНИВО. - Ф. 113. - Оп. 98. - Д. 83.-154 л.

34. Статистические итоговые данные обследования бюджетов рабочих и колхозников по Саратовской области за III квартал 1955 г. (докладная записка на имя секретаря Саратовского обкома КПСС Г. А. Боркова) // ГАНИСО. - Ф. 594. - Оп. 2. Д. $3212 .-347$ л.

35. Стенограмма V областной межсоюзной конференции профсоюзов Калмыцкой АССР (от 7 сентября 1965 г.) // НАРК. - Ф. Р-13. - Оп. 4. Д. 22. -209 л.

36. Таблица рождаемости по годам (Россия). Электрон. текстовые дан. - Режим доступа: https:// worldtable.info/gosudarstvo/tablica-rozhdaemosti-pogodam-rossija.html (дата обращения: 10.04.2019).

\section{REFERENCES}

1. Vasileva L. Rol zhenshchiny v sotsialnoekonomicheskoy i politicheskoy sferakh sovetskogo obshchestva $v$ 1945-1965 gg. (na materialakh Saratovskoy oblasti): diss. kand. ist. nauk [The Role of Women in the Socio-Economic and Political Spheres of Soviet Society in 1945-1965 (On Materials of Saratov Region). Cand. hist. sci. diss.]. Saratov, 2004. 247 p.

2. Vypiska iz protokola № 25 zasedaniya Prezidiuma TsK KPSS (ot 12 avgusta 1953 g.) [Extract from the Minutes no. 25 of the Meeting of the Presidium of the Central Committee of the Communist Party of the Soviet Union (August 12, 1953)]. RGANI [Russian State Archive of Recent History], F. 3, Op. 31, D. 17.1701.

3. Doklad o sostoyanii razvitiya seti detskikh doshkolnykh uchrezhdeniy Saratovskoy oblastiv $1953 \mathrm{~g}$. [Report on the State of Development of the Network of Preschool Institutions for Children in Saratov Region in 1953]. GANISO [State Archive of Recent History of Saratov Region], F. 594, Op. 2, D. 2713. 3181.
4. Doklad o sostoyanii razvitiya seti detskikh doshkolnykh uchrezhdeniy Saratovskoy oblasti v $1984 \mathrm{~g}$. [Report on the State of Development of the Network of Preschool Institutions in Saratov Region in 1984]. GANISO [State Archive of Recent History of Saratov Region], F. 6164, Op. 8-pr., D. 1385. 521.

5. Zasedaniya Verkhovnogo Soveta Kalmytskoy ASSR tretyego sozyva, shestaya sessiya (27 iyulya 1966 g.): stenogr. otchet [Meetings of the Supreme Council of the Kalmyk ASSR of the Third Convocation, Sixth Session (July 27, 1966). Verbatim Record]. Elista, Kalmizdat Publ., 1966. 66 p.

6. Issledovanie: detskie sady $v$ RF nedostupny dlya $35 \%$ detey [Study: Kindergartens in Russia Are not Available for 35\% of Children]. URL: https://tass.ru/ obschestvo/4114004 (accessed 10 April 2019).

7. Kasimovsky E. Rol proizvoditelnosti truda $\mathrm{v}$ povyshenii blagosostoyaniya naroda na sovremennom etape [Role of Labor Productivity in Improving the Well-Being of the People at the Present Stage]. Sotsialisticheskiy obraz zhizni $i$ narodnoe blagosostoyanie [Socialist Way of Life and People's Welfare]. Saratov, Izd-vo Saratovskogo universiteta, 1975, pp. 110-120.

8. KPSS v rezolyutsiyakh i resheniyakh syezdov, konferentsiy i plenumov TsK (1898-1988). V $16 t$. T. 8. 1946-1955 [The CPSU in Resolutions and Decisions of Congresses, Conferences and Plenums of the Central Committee (1998-1988). In 16 Vols. Vol. 8. 1946-1955]. Moscow, Politizdat Publ., 1985. 542 p.

9. Leontyeva E. Sotsialnaya politika na Yuzhnom Urale v period pravleniya N.S. Khrushcheva: dis. ... kand. ist. nauk [Social Policy in the Southern Urals During the Rule of N.S. Khrushchev. Cand. hist. sci. diss.]. Orenburg, 2013. 237 p.

10. Materialy $k$ otchetnomu dokladu na XVI Saratovskoy oblastnoy mezhsoyuznoy konferentsii profsoyuzov (ot 26 yanvarya 1985 g.) [Materials to the Report at the $16^{\text {th }}$ Saratov Regional Inter-Union Conference of Trade Unions (Dated January 26, 1985)]. GANISO [State Archive of Recent History of Saratov Region], F. 6164, Op. 8, D. 1416.3421.

11. Materialy po nakazam izbirateley deputatam Verkhovnogo Soveta Kalmytskoy ASSR (ot 20 aprelya 1962 g.) [Materials on the Orders of Voters to Deputies of the Supreme Soviet of the Kalmyk ASSR (Dated April 20, 1962)]. NARK [National Archive of the Republic of Kalmykia], F. P-1, Op. 4, D. 175. 1571.

12. Nakazy izbirateley kandidatam $\mathrm{v}$ deputaty oblastnogo Soveta [Voters Orders for Candidates for Deputies of the Regional Council]. GAAO [State Archive of Astrakhan Region], F. R-2233, Op. 15, D. 339.4231 .

13. Nakazy izbirateley deputatam oblastnogo Soveta VIII sozyva i materialy po ikh vypolneniyu [Voters Orders to Deputies of the Regional Council of 
the $8^{\text {th }}$ Convocation and Materials on Their Implementation]. GASO [State Archive of Saratov Region], F. R-1738, Op. 1, D. 1068. 1691.

14. Nakazy izbirateley deputatam oblastnogo Soveta i materialy po ikh vypolneniyu [Voters Orders to Deputies of the Regional Council and Materials on Their Implementation]. GASO [State Archive of Saratov Region], F. R-1738, Op. 8, D. 1254. 1841.

15. Nakazy i predlozheniya izbirateley, vyskazannye pri vstrechakh deputatov Verkhovnogo Soveta SSSR i oblastnogo Soveta [Orders and Proposals of Voters Expressed at Meetings of Deputies of the Supreme Soviet of the USSR and the Regional Council]. GAVO [State Archive of Volgograd Region], F. R-2115, Op. 6, D. 1877. 1311.

16. Nakazy i predlozheniya izbirateley, dannye deputatam Oblsoveta v 1965 g. [Orders and Proposals of Voters Given to the Deputies of the Regional Council in 1965]. GAVO [State Archive of Volgograd Region], F. R-2115, Op. 6, D. 2026. 1631.

17. Narodnoe khozyaystvo Astrakhanskoy oblasti: stat. sb. [National Economy of Astrakhan Region. Statistical Collection]. Saratov, Gosstatizdat, 1958.160 p.

18. Narodnoe khozyaystvo Kalmytskoy ASSR: stat. sb. [National Economy of the Kalmyk ASSR. Statistical Collection]. Elista, Kalmizdat, 1960. 137 p.

19. Narodnoe khozyaystvo RSFSR: stat. sb. [National Economy of the RSFSR. Statistical Collection]. Moscow, Gosstatizdat, 1957.372 p.

20. Narodnoe khozyaystvo RSFSR v 1958 godu: stat. ezhegodnik [National Economy of the RSFSR in 1958. Statistical Yearbook]. Moscow, Gosstatizdat, 1959. 508 p.

21. Narodnoe khozyaystvo RSFSR v 1964 godu: stat. ezhegodnik [National Economy of the RSFSR in 1964. Statistical Yearbook]. Moscow, Statistika Publ., $1965.576 \mathrm{p}$.

22. Narodnoe khozyaystvo RSFSR v 1985 godu: stat. ezhegodnik [National Economy of the RSFSR in 1985. Statistical Yearbook]. Moscow, Finansy i statistika Publ., 1986. 397 p.

23. Narodnoe khozyaystvo Saratovskoy oblasti za 50 let Sovetskoy vlasti: stat. sb. [National Economy of Saratov Region for 50 Years of the Soviet Power. Statistical Collection]. Saratov, Statistika Publ., 1967.454 p.

24. Narodnoe khozyaystvo Stalingradskoy oblasti: stat. sb. [National Economy of Stalingrad Region. Statistical Collection]. Saratov, Gosstatizdat, 1957.319 p.

25. Osnovnye napravleniya razvitiya proizvoditelnykh sil Astrakhanskoy oblasti na period do 1990 goda: nauch. dokl. [Main Directions in Development of Productive Forces of Astrakhan Region for the Period till 1990. Scientific Report]. Moscow, Tsentralnyy nauchno-issledovatelskiy eksperiment Publ., Institut Gosplana SSSR, 1978. 243 p.
26. Otchetnyy doklad Volgogradskogo oblastnogo soveta professionalnykh soyuzov za 19601961 gg. na VII Volgogradskoy oblastnoy mezhsoyuznoy konferentsii profsoyuzov (2-3 marta 1962 g.) [Summary Report of the Volgograd Regional Council of Trade Unions for 1960-1961 at the $7^{\text {th }}$ Volgograd Regional Inter-Union Conference of Trade Unions (March 2-3, 1962)]. GAVO [State Archive of Volgograd Region], F. R-523, Op. 1, D. 858. 2201.

27. Perechen nakazov izbirateley deputatam oblastnogo Soveta deputatov [List of Voters Orders to Deputies of the Regional Council]. GASO [State Archive of Saratov Region], F. R-1738, Op. 8, D. 2014-a. 1901.

28. Programma Kommunisticheskoy partii Sovetskogo Soyuza: Prinyata XXII syezdom KPSS [Program of the Communist Party of the Soviet Union. Adopted by the $22^{\text {nd }}$ Congress of the CPSU]. Moscow, Politizdat, 1976. $144 \mathrm{p}$.

29. Protokol V sessii Saratovskogo oblastnogo Soveta (ot 23 marta 1978 g.) [Minutes of the $5^{\text {th }}$ Session of the Saratov Regional Council (Dated March 23, 1978)]. GASO [State Archive of Saratov Region], F. R-1738, Op. 8, D. 1429-a. 701.

30. Protokoly predvybornykh sobraniy izbirateley, posvyashchennykh vstreche s kandidatami $\mathrm{v}$ deputaty oblastnogo soveta deputatov trudyashchikhsya [Protocols of Electoral Assemblies of Voters Devoted to a Meeting with Candidates for Deputies of the Regional Council of Deputies of Workers]. GAAO [State Archive of Astrakhan Region], F. R-2233, Op. 15, D. 514. 4781.

31. Pyzhikov A. Khrushchevskaya «ottepel» [Khrushchevs “Thaw"]. Moscow, OLMA-PRESS Publ., 2002. 511 p.

32. Rabota organizatsionno-metodicheskikh kabinetov oblastnykh i respublikanskikh bolnits po lechebno-profilakticheskoy pomoshchi detyam. Rol i organizatsionnye formy raboty detskogo otdeleniya bolnitsy: dokl. na Vseros. soveshch. gl. vrachey resp., kraev., obl. bolnits po obmenu opytom raboty 2529 okt. 1955 g. [The Work of Organizational and Methodological Offices of Regional and Republican Hospitals on Treatment-and-Prophylactic Care for Children. The Role and Organizational Modalities of the Childrens Department in Hospitals (Report at the All-Russian Meeting of the Chief Doctors of the Republican, Krai and Regional Hospitals to Share Experience of Work on October 25-29, 1955)]. GARF [State Archive of the Russian Federation], F. A-482, Op. 50, D. 213. 2021.

33. Spravka o sostoyanii vospitaniya i obsluzhivaniya detey $v$ doshkolnykh uchrezhdeniyakh oblasti v svete trebovaniy XXV syezda KPSS (ot 27 iyulya 1976 g.) [Information Sheet on the State of Upbringing and Care of Children in Preschool Institutions of the Region in the Light of the 
Requirements of the $25^{\text {th }}$ Congress of the CPSU (Dated July 27, 1976)]. TSSDNIVO [Center for Documentation of Contemporary History of the Volgograd Region], F. 113, Op. 98, D. 83. 1541.

34. Statisticheskie itogovye dannye obsledovaniya byudzhetov rabochikh i kolkhoznikov po Saratovskoy oblasti za III kvartal $1955 \mathrm{~g}$. (dokladnaya zapiska na imya sekretarya Saratovskogo obkoma KPSS G. A. Borkova) [Statistical Data of a Survey on the Budgets of Workers and Collective Farmers in Saratov Region for the Third Quarter of 1955 (Memorandum Addressed to the Secretary of the Saratov Regional Committee of the CPSU,
G.A. Borkov)]. GANISO [State Archive of Recent History of Saratov Region], F. 594, Op. 2, D. 3212. 3471.

35. Stenogramma V oblastnoy mezhsoyuznoy konferentsii profsoyuzov Kalmytskoy ASSR (ot 7 sentyabrya $1965 \mathrm{~g}$.) [Transcript of the $5^{\text {th }}$ Regional Inter-Union Conference of Trade Unions of the Kalmyk Autonomous Soviet Socialist Republic (Dated September 7, 1965)]. NARK [National Archive of the Republic of Kalmykia], F. R-13, Op. 4, D. 22. 2091.

36. Tablitsa rozhdaemosti po godam (Rossiya) [Table of Birth Rate by Year (Russia)]. URL: https:// worldtable.info/gosudarstvo/tablica-rozhdaemosti-pogodam-rossija.html (accessed 10 April 2019).

\section{Information About the Author}

Alexey A. Gumenyuk, Doctor of Sciences (History), Associate Professor, Department of Domestic History and Historiography, Saratov State University named after N.G. Chernyshevskiy, Astrakhanskaya St., 83, 410012 Saratov, Russian Federation, GumenukAA@rambler.ru, https://orcid.org/0000-0001-7024-2142

\section{Информация об авторе}

Алексей Анатольевич Гуменюк, доктор исторических наук, доцент кафедры отечественной истории и историографии, Саратовский государственный университет им. Н.Г. Чернышевского, ул. Астраханская, 83, 410012 г. Саратов, Российская Федерация, GumenukAA@rambler.ru, https://orcid.org/0000-0001-7024-2142 